\title{
Study on the Application of Flipped Classroom Teaching Mode in College English Teaching Practice
}

\author{
Huijuan Liu \\ Linyi University, Shandong 273400, China \\ lyfxlhj@sina.com
}

Keywords: Flipped Classroom; Teaching Mode; College English.

\begin{abstract}
At present, the research on the application of the flipped classroom teaching mode in the higher education curriculum in China is mostly focused on the introduction of the theory and the teaching design, lacking empirical research. Therefore, this paper studied the application of the flipped classroom teaching mode in College English teaching practice. This paper first of all gave the concept of the flipped classroom teaching mode, then designed the experiment of flipped classroom teaching mode in College English teaching practice, and divided students participated in the experiment into the control class and the experimental class two groups. We gave specific methods and processes of the experiment, and collected experimental data. The experimental results showed that: on the whole, the flipped classroom teaching mode had obvious advantages than the traditional classroom teaching, which played a positive role in promoting and improving the effectiveness of College English teaching. At the same time, the flipped classroom teaching model established the initiative status of learners, provided personalized learning environment and a variety of learning methods, and effectively promoted the students' communicative ability.
\end{abstract}

\section{Introduction}

The Ministry of Education "College English curriculum requirements" pointed out that, "College English teaching is divided into compulsory stage and elective stage, and the culture teaching is an important part of the elective stage". The purpose is to improve the students' cultural quality and ability of cross culture communication. Compared with the required courses of College English, the elective course has less class time, the class scale is not stable, and the teaching order is difficult to control. As a result, it is rather urgent to enhance the elective course teaching effect. How to fully achieve the goal of teaching in a limited period of time is the concern of the majority of teachers. Flipped classroom model is increasingly popular in recent years in America. It is a new teaching mode based on information based means, aiming at making full use of classroom time, achieving personalized learning, and promoting the development of the ability of autonomous learning and cooperative learning consciousness. This teaching mode can fit the current direction of reform in education, and it has become one of the the teaching modes front-line teachers interested in. Combined with the current situation of College English teaching, this paper takes the Chinese culture teaching in College English teaching as an example to study the application of the flipped classroom teaching mode in the teaching practice.

\section{Research content}

\subsection{Concept of flipped classroom teaching mode}

As a new teaching mode, flipped classroom has set off a revolution in education since the rise of the United States. Taking Eric Mazur and so on in Harvard University as the pioneer in the exploration, the Bangladesh nationality American Salman Khan built the prototype of the model. The domestic research on flipped classroom time is not long, but with the combination of theory and practice of the flipped classroom, the domestic scholars made the definition: Zhang Jinlei and so on believed that the flipped classroom knowledge teaching was completed after class aided by information technology, while knowledge internalization was completed in the classroom by with the 
help of teachers and students. It is a new teaching mode of changing the role of teachers and students in traditional teaching and using classroom time for re-planning; Zhong Xiaoliu and so on held that flipped classroom is, in the environment of information, a new teaching mode that teachers provide learning resources with teaching video as the main form, students complete watching and learning teaching video and so on learning resources before class, and teachers and students cooperate to finish the homework, answering questions, interaction and other activities in class.

The paper, combined with scholars' views and personal understanding, defined the flipped classroom as educators using computer and network technology to make video teaching and learning tasks list for student's autonomous learning before class. Through the feedback of learning system, we can know students' self-learning situation, make teaching plan, construct independent inquiry and cooperative interaction learning environment in class for students, and guide students to discuss problems and do the corresponding practice, so as to promote the knowledge internalization.

\subsection{The experimental design of the flipped classroom teaching mode in College English teaching practice}

\subsubsection{Experiment object}

This experiment selected students reached the CET four level of 2014 as the experimental objects, allowing the part of students' independent courses selection through the teaching management platform of a university in Xi'an City. There were a total of 100 students selecting China culture courses, and these students were divided into the experimental class and the control class two classes. The experimental class and the control class were the same in class time.

\subsubsection{Experiment design}

The content of this course is based on the "Chinese Culture and English Course", which is supplemented by the English extended course related books. According to the requirements of a university in Xi'an to expand the elective courses, students can choose their own courses [1]. Students were divided into the experimental class and the control class two classes in accordance with the different class's time. The experimental class was designed and implemented by using the flipped classroom teaching mode, while the control class adopted multimedia course-ware to assist class teaching mode. At the end of the semester, adopt the unified close book examination. The experimental period is one semester. The purpose of the experiment is to verify the difference of the teaching effect of the flipped classroom model compared with the traditional teaching mode.

Before the experiment, the students' attitude towards Chinese traditional culture was investigated by questionnaire, which was the basis of observing the change of students' attitude and the mastery of knowledge. After the experiment, the questionnaire was designed according to the different points in the teaching practice. The purpose was to understand the attitude and acceptance of the students to the flipped classroom teaching mode.

In the experiment, we need to use SPSS statistical software to analyze the pretest and post test scores, and use independent sample t test to get the conclusion.

2.2.3 Research on the course of Chinese culture teaching experiment based on flipped classroom teaching mode

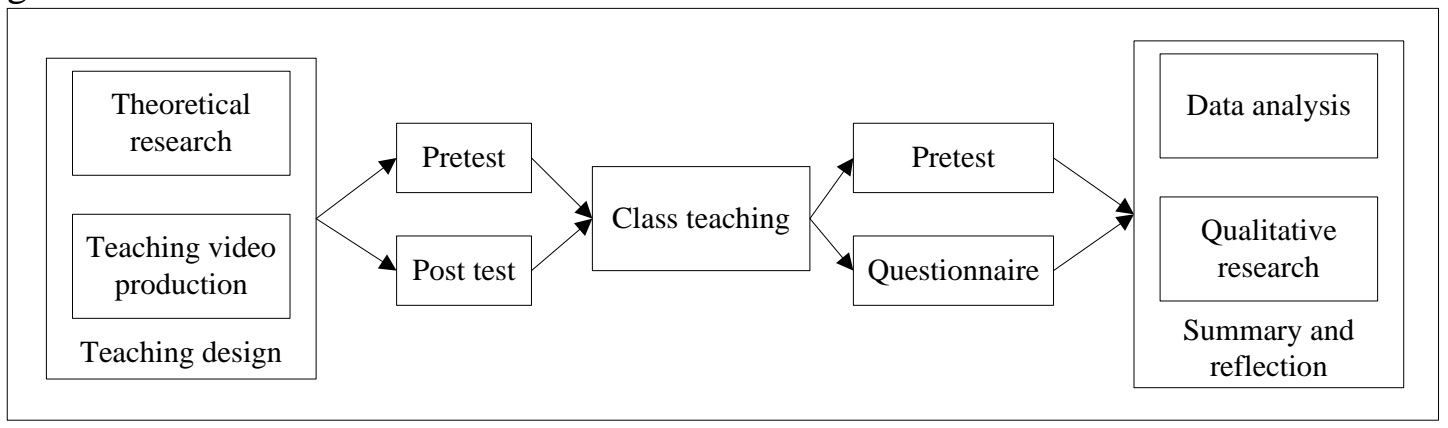

Figure 1. The flow chart of the experimental teaching of Chinese culture based on the flipped classroom teaching mode

This study started from March 2016 and ended in July 2016, lasted for a semester. The research process is shown in figure 1. 
1) In the teaching design stage, according to the flipped classroom teaching mode and Bloom education target classification table, we determine the teaching objectives, and teaching focus and difficulty of each unit, extensively use network resources and various software to make teaching video, and design the corresponding practice according to different levels of teaching objectives. The teaching content contains four aspects of humanistic ideas, cultural heritage, aesthetic art and traditional customs, as shown in table 1.

Table 1. A list of teaching contents of Chinese culture

\begin{tabular}{|c|c|}
\hline \multirow{4}{*}{$\begin{array}{c}\text { Part I } \\
\text { Wisdom and Beliefs }\end{array}$} & Unit 1 Confucian Thought on Heaven and Humanity \\
\hline & Unit 2 Laozi's Philosophy of Non-action \\
\hline & Unit 3 The Temple of Heaven: Reverence with Awe and Gratitude \\
\hline & Unit 4 Eco-awareness in Traditional Chinese Culture \\
\hline \multirow{3}{*}{$\begin{array}{c}\text { Part II } \\
\text { Creativity and } \\
\text { Exchange }\end{array}$} & Unit 5 Chinese Character and Calligraphy \\
\hline & Unit 6 The Silk Road and Openness of the Great Tang \\
\hline & $\begin{array}{l}\text { Unit } 7 \text { The Great Wall and The Forbidden City: Glorious and } \\
\text { Awe-inspiring }\end{array}$ \\
\hline \multirow{4}{*}{$\begin{array}{c}\text { Part III } \\
\text { Art and Aesthetics }\end{array}$} & Unit 8 Peking Opera: Artistry of Performers \\
\hline & Unit 9 Flying Strokes of Calligraphy \\
\hline & Unit 10 Gardens South of the Yangtze River \\
\hline & Unit 11 Porcelain: Calling Card of Chinese Culture \\
\hline \multirow{4}{*}{$\begin{array}{c}\text { Part IV } \\
\text { Folk Customs }\end{array}$} & Unit 12 Customs and Charms of Old Beijing \\
\hline & Unit 13 Traditional Chinese Medicine \\
\hline & Unit 14 Life with Fragrant Tea \\
\hline & al Arts and Cuju \\
\hline
\end{tabular}

2) Conduct a questionnaire survey and the pretest of traditional cultural knowledge of the experimental class and the control class before the start of the class, aimed at knowing the basic attitude of students to Chinese traditional culture and understanding degree of traditional cultural knowledge.

3) After entering the classroom teaching stage, the students in the experimental class and the control class are taught by the same teacher using different teaching modes, but same in the teaching progress.

The control class is taught by traditional ppt assisted classroom teaching mode, and each lesson is 90 minutes, during which the teachers taught for about 70 minutes, and the remaining time is used to organize the students to discuss or do classroom exercise and check the answers in class.

The students in the experimental class, according to the "heterogeneity within the group, homogeneity inter group" principle, on the basis of basic knowledge pre-test and CET four examination results as the reference, are divided into 4-5 students interactive study group. They watch the video before the class or at the beginning of the course, and finish the memory and understanding level practice. Followed by, they need to make a comparison of the answer in groups, and find deficiencies from each other; then, teachers give the comprehensive use level practice, students discuss in groups, and complete the results report. The results show that encouraging students is presented in different forms, each class is composed of 2 groups of students to actively show. The groups with no chance to show can upload the results in text, audio and video form to the mailbox of the public course for others' learning and reference.

4) After the classroom teaching is completed, carry on the questionnaire survey to the students in the experimental class. The questionnaire, for the implementation status of this model in teaching, we design from teaching content teaching before class, in the course of communication learning activities, and learning effect evaluation and the overall situation these four aspects [2]. At the end of the semester, carry out unified closed book examination of the two class's students, and take the scores as the post test results. Papers is the traditional types of College English based, subjective and objective questions with the ratio of 3: 7. It is designed from the memory test level, understanding 
level, and comprehensive utilization level these three dimensions, and each dimension is not confined to a test question.

On the basis of the above research, this paper carries on the analysis and reflection from the two angles of quantitative research and qualitative research.

\section{Research results}

\subsection{Pretest data and analysis}

1) Students' cognition of Chinese traditional culture

The statistical results of pretest scores of basic knowledge of traditional culture are shown in table 2.

Table 2. The statistical results of pretest scores of basic knowledge of traditional culture (with full mark of 15)

\begin{tabular}{|c|c|c|c|c|c|}
\hline & Category & $\mathrm{N}$ & $\begin{array}{c}\text { Mean } \\
\text { value }\end{array}$ & $\begin{array}{c}\text { Standard } \\
\text { deviation }\end{array}$ & $\begin{array}{c}\text { Standard deviation of the } \\
\text { mean value }\end{array}$ \\
\hline \multirow{2}{*}{$\begin{array}{c}\text { Total } \\
\text { score }\end{array}$} & $\begin{array}{c}\text { The experimental } \\
\text { class }\end{array}$ & 50 & 7.43 & 1.786 & 218 \\
\cline { 2 - 6 } & The control class & 50 & 7.29 & 1.216 & 218 \\
\hline
\end{tabular}

The results show that, before the start of the experiment, students' traditional culture is weak. The average value of the control class is 7.43 , and the average value of the experimental class is 7.29 , indicating that students' familiarity with the basic knowledge of traditional culture is general [3].

In the traditional culture basic knowledge pre-test scores of the experimental class and the control class shown in table 3 , sig $=0.164$, more than 0.05 , showing the homogeneity of variance. At the same time, $\mathrm{P}=0.672>0.05$, the sample of the two groups has no significant difference. It shows that the basic level of the experimental class and the control class are similar and comparable.

Table 3. Independent sample t test of traditional culture basic knowledge pre-test scores

\begin{tabular}{|c|c|c|c|c|c|c|c|c|c|c|}
\hline \multirow{3}{*}{\multicolumn{2}{|c|}{$\begin{array}{l}\text { Independent } \\
\text { sample test }\end{array}$}} & \multicolumn{2}{|c|}{$\begin{array}{l}\text { Levene test } \\
\text { of variance } \\
\text { equation }\end{array}$} & \multicolumn{7}{|c|}{$\mathrm{t}$ test of mean value equation } \\
\hline & & \multirow[b]{2}{*}{$\mathrm{F}$} & \multirow[b]{2}{*}{ Sig } & \multirow[b]{2}{*}{$\mathrm{t}$} & \multirow[b]{2}{*}{$\mathrm{df}$} & \multirow[b]{2}{*}{$\begin{array}{c}\text { Sig } \\
\text { (bilateral) }\end{array}$} & \multirow[b]{2}{*}{$\begin{array}{c}\text { Mean } \\
\text { difference }\end{array}$} & \multirow[b]{2}{*}{$\begin{array}{c}\text { Standad } \\
\text { error }\end{array}$} & \multicolumn{2}{|c|}{$\begin{array}{l}95 \% \text { confidence } \\
\text { interval of } \\
\text { difference } \\
\end{array}$} \\
\hline & & & & & & & & & $\begin{array}{c}\text { Lower } \\
\text { limit }\end{array}$ & $\begin{array}{l}\text { Upper } \\
\text { limit }\end{array}$ \\
\hline \multirow{2}{*}{$\begin{array}{l}\text { Total } \\
\text { score }\end{array}$} & $\begin{array}{l}\text { Assuming } \\
\text { that the } \\
\text { variance is } \\
\text { equal. }\end{array}$ & 1.842 & .164 & .405 & 97 & .688 & .143 & .354 & -.560 & .7845 \\
\hline & $\begin{array}{l}\text { Assuming } \\
\text { that the } \\
\text { variance is } \\
\text { not equal. }\end{array}$ & & & .459 & 82.423 & .646 & .143 & .309 & -.472 & .757 \\
\hline
\end{tabular}

2) Students' English proficiency pre-test

The results of the test group in the control class and the experimental class are shown in table 4.

Table 4. Statistics of English level scores of the two classes (with full mark of 710)

\begin{tabular}{|c|c|c|c|c|c|}
\hline \multirow{2}{*}{ Total score } & Category & $\mathrm{N}$ & Mean value & $\begin{array}{c}\text { Standard } \\
\text { deviation }\end{array}$ & $\begin{array}{c}\text { Standard } \\
\text { deviation of the } \\
\text { mean value }\end{array}$ \\
\hline \multirow{2}{*}{ The experimental } \\
\cline { 2 - 5 } & class & 50 & 523.48 & 34.734 & 4.556 \\
\hline
\end{tabular}

The results show that the two class's students' English proficiency is generally good. The scores of students in the CET four examination are as the reference in this experiment. Two classes' average 
scores are 520 points or more, which can ensure that students have basic understanding of English expression in the process of teaching.

Analyzing table 5 , it is seen that, sig $=0.842>0.05$, showing homogeneity of variance, and $\mathrm{P}=0.885>0.05$, there was no significant difference between the two groups. It indicates that the two class's students' English level is similar, with comparability.

Table 5. Independent sample t test of English level score of the two classes

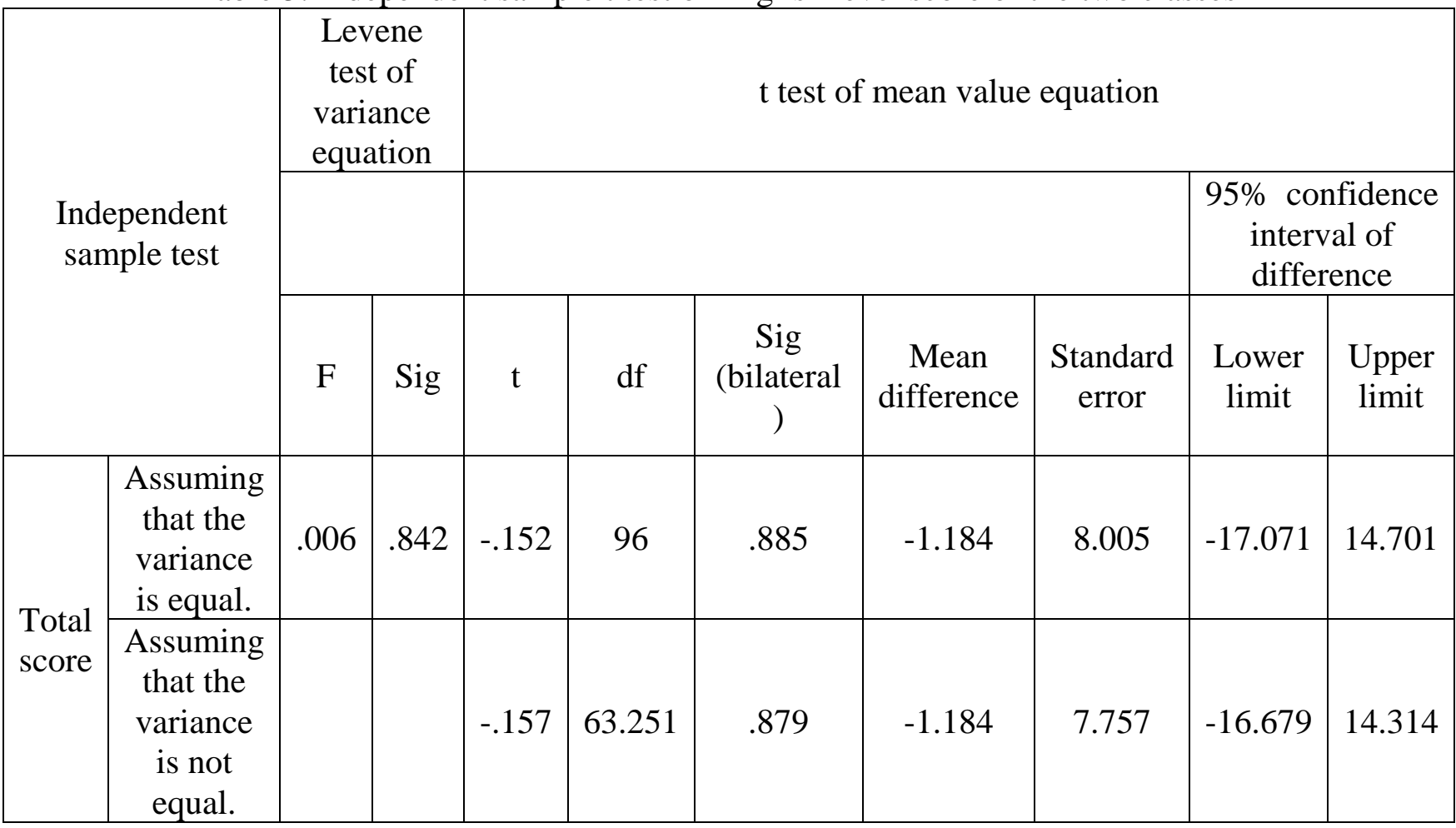

\subsection{Post test data and analysis}

1) Descriptive analysis of post test scores

Take the Chinese culture curriculum final examination result as the test result to carry on the analysis. As can be seen from table 6, the average score of the final exam is 66.71, the standard error is 0.866 , the standard deviation is 8.570 , and the variance is about 73.433 [4]. The skewness coefficient is -0.406 , the peak degree coefficient is -0.024 , and the coefficient approaches 0 . As a result, the proposition is basically reasonable.

Table 6. Independent sample t test of English level scores in the two classes

\begin{tabular}{|c|c|c|c|c|c|c|c|c|c|c|c|}
\hline & $\mathrm{N}$ & & & \multicolumn{2}{|c|}{ Mean value } & $\begin{array}{c}\text { Standard } \\
\text { deviation }\end{array}$ & Variance & \multicolumn{2}{|c|}{ Skewness } & \multicolumn{2}{c|}{ Peak degree } \\
\cline { 2 - 12 } & Statistics & Statistics & Statistics & Statistics & $\begin{array}{c}\text { Standard } \\
\text { error }\end{array}$ & Statistics & Statistics & Statistics & $\begin{array}{c}\text { Standard } \\
\text { quantity }\end{array}$ & Statistics & $\begin{array}{c}\text { Standard } \\
\text { quantity }\end{array}$ \\
\hline $\begin{array}{c}\text { Effective } \\
\text { N (List } \\
\text { status) }\end{array}$ & 100 & 40 & 85 & 66.72 & .866 & 8.571 & 73.443 & -.406 & .244 & -.024 & .483 \\
\cline { 2 - 11 }
\end{tabular}

2) Post test score difference test of the control class and the experimental class

Table 7. Post test scores statistics (with full mark of 100)

\begin{tabular}{|c|c|c|c|c|c|}
\hline & Category & $\mathrm{N}$ & $\begin{array}{c}\text { Mean } \\
\text { value }\end{array}$ & $\begin{array}{c}\text { Standard } \\
\text { deviation }\end{array}$ & $\begin{array}{c}\text { Standard deviation of the } \\
\text { mean value }\end{array}$ \\
\hline \multirow{2}{*}{$\begin{array}{c}\text { Total } \\
\text { score }\end{array}$} & $\begin{array}{c}\text { The experimental } \\
\text { class }\end{array}$ & 50 & 70.58 & 7.297 & 1.311 \\
\cline { 2 - 6 } & The control class & 50 & 65.34 & 8.839 & 1.079 \\
\hline
\end{tabular}

The results shows that after the teaching is completed, the control class and the experimental class have a basic understanding of the traditional Chinese culture. The average score of the control class is 65.34, the average score of the experimental class is 70.58, the score of the experimental class higher than that of the control class. 
Table 8. Posttest total score independent sample t test of the control class and the experimental class

\begin{tabular}{|c|c|c|c|c|c|c|c|c|c|c|}
\hline \multirow{3}{*}{\multicolumn{2}{|c|}{$\begin{array}{c} \\
\text { Independent } \\
\text { sample test }\end{array}$}} & \multicolumn{2}{|c|}{$\begin{array}{c}\text { Levene test } \\
\text { of variance } \\
\text { equation }\end{array}$} & \multicolumn{7}{|c|}{$\mathrm{t}$ test of mean value equation } \\
\hline & & \multirow[b]{2}{*}{$\mathrm{F}$} & \multirow[b]{2}{*}{ Sig } & \multirow[b]{2}{*}{$\mathrm{t}$} & \multirow[b]{2}{*}{ df } & \multirow[b]{2}{*}{$\begin{array}{c}\text { Sig } \\
\text { (bilateral } \\
\text { ) }\end{array}$} & \multirow[b]{2}{*}{$\begin{array}{c}\text { Mean } \\
\text { difference }\end{array}$} & \multirow[b]{2}{*}{$\begin{array}{c}\text { Standard } \\
\text { error }\end{array}$} & \multicolumn{2}{|c|}{$\begin{array}{c}95 \% \\
\text { confidence } \\
\text { interval of } \\
\text { difference }\end{array}$} \\
\hline & & & & & & & & & $\begin{array}{c}\text { Lower } \\
\text { limit }\end{array}$ & $\begin{array}{l}\text { Upper } \\
\text { limit }\end{array}$ \\
\hline \multirow{2}{*}{$\begin{array}{l}\text { Total } \\
\text { score }\end{array}$} & $\begin{array}{l}\text { Assuming } \\
\text { that the } \\
\text { variance } \\
\text { is equal. }\end{array}$ & 3.153 & .081 & -2.302 & 96 & .027 & -4.193 & 1.822 & -7.808 & -.577 \\
\hline & $\begin{array}{l}\text { Assuming } \\
\text { that the } \\
\text { variance } \\
\text { is not } \\
\text { equal. }\end{array}$ & & & -2.471 & 69.893 & .019 & -4.193 & 1.698 & -7.579 & -.806 \\
\hline
\end{tabular}

From the analysis of table 8 , it can be seen that, sig $=0.081>0.05$, showing homogeneity of variance. At the same time, $\mathrm{P}=0.027<0.05$, the total score of the experimental class is significantly higher than the results of the control class. This shows that in the course of Chinese culture, the flipped classroom teaching model has obvious advantages over the traditional classroom teaching in general.

3) Post test scores classification test of the control class and the experimental class

Table 9. Post test scores classification test group statistics

\begin{tabular}{|c|c|c|c|c|c|}
\hline \multicolumn{2}{|c|}{ Category } & $\mathrm{N}$ & Mean & $\begin{array}{r}\text { Standard } \\
\text { deviation }\end{array}$ & $\begin{array}{l}\text { Standard deviation of the } \\
\text { mean }\end{array}$ \\
\hline \multirow{2}{*}{ Memory } & $\begin{array}{l}\text { The experimental } \\
\text { class }\end{array}$ & 50 & 14.54 & 2.776 & .339 \\
\hline & The control class & 50 & 14.32 & 2.786 & .500 \\
\hline \multirow[t]{2}{*}{ Understanding } & $\begin{array}{c}\text { The experimental } \\
\text { class }\end{array}$ & 50 & 32.42 & 3.806 & .465 \\
\hline & The control class & 50 & 34.29 & 4.368 & .785 \\
\hline \multirow{2}{*}{$\begin{array}{c}\text { Comprehensive } \\
\text { use }\end{array}$} & $\begin{array}{c}\text { The experimental } \\
\text { class }\end{array}$ & 50 & 18.43 & 5.628 & .688 \\
\hline & The control class & 50 & 20.97 & 4.868 & .874 \\
\hline
\end{tabular}

Analysis of Table 9 shows that in the memory dimension teaching objectives, the control class scores are slightly higher than those of the experimental class; in the understanding dimension teaching objectives, the performance of the experimental class is 1.87 points higher than the control class [5]; in the comprehensive use dimension teaching objectives, the experimental class is 2.54 points higher than the control class. 
Table 10. Post test scores classification test independent sample t test

\begin{tabular}{|c|c|c|c|c|c|c|c|c|c|c|}
\hline \multirow{3}{*}{\multicolumn{2}{|c|}{ Independent sample test }} & \multicolumn{2}{|c|}{$\begin{array}{c}\text { Levene test } \\
\text { of variance } \\
\text { equation }\end{array}$} & \multicolumn{7}{|c|}{$\mathrm{t}$ test of mean value equation } \\
\hline & & \multirow[b]{2}{*}{ F } & \multirow[b]{2}{*}{ Sig } & \multirow[b]{2}{*}{$\mathrm{t}$} & \multirow[b]{2}{*}{ df } & \multirow[b]{2}{*}{$\begin{array}{c}\text { Sig } \\
\text { (bilateral } \\
\text { ) }\end{array}$} & \multirow[b]{2}{*}{$\begin{array}{c}\text { Mean } \\
\text { differenc } \\
\mathrm{e}\end{array}$} & \multirow[b]{2}{*}{$\begin{array}{l}\text { Standar } \\
\text { d error }\end{array}$} & \multicolumn{2}{|c|}{$\begin{array}{c}\text { 95\% } \\
\text { confidence } \\
\text { interval of } \\
\text { difference }\end{array}$} \\
\hline & & & & & & & & & $\begin{array}{l}\text { Lower } \\
\text { limit }\end{array}$ & $\begin{array}{l}\text { Upper } \\
\text { limit }\end{array}$ \\
\hline \multirow[b]{2}{*}{ Memory } & $\begin{array}{l}\text { Assuming } \\
\text { that the } \\
\text { variance } \\
\text { is equal. }\end{array}$ & .002 & $\begin{array}{c}.96 \\
2\end{array}$ & .356 & 96 & .723 & 215 & .604 & -.984 & 1.413 \\
\hline & $\begin{array}{l}\text { Assuming } \\
\text { that the } \\
\text { variance } \\
\text { is not } \\
\text { equal. }\end{array}$ & & & .355 & $\begin{array}{c}58.31 \\
2\end{array}$ & .724 & 215 & .604 & -.995 & 1.424 \\
\hline \multirow[b]{2}{*}{ Understanding } & $\begin{array}{l}\text { Assuming } \\
\text { that the } \\
\text { variance } \\
\text { is equal. }\end{array}$ & $\begin{array}{c}1.14 \\
9\end{array}$ & $\begin{array}{c}.28 \\
7\end{array}$ & $\begin{array}{c}-2.16 \\
0\end{array}$ & 96 & .033 & -1.872 & .867 & -3.593 & -.152 \\
\hline & $\begin{array}{l}\text { Assuming } \\
\text { that the } \\
\text { variance } \\
\text { is not } \\
\text { equal. }\end{array}$ & & & $\begin{array}{c}-2.05 \\
3\end{array}$ & $\begin{array}{c}51.87 \\
5\end{array}$ & .045 & -1.872 & .912 & -3.703 & -.042 \\
\hline \multirow{2}{*}{$\begin{array}{c}\text { Comprehensiv } \\
\text { e use }\end{array}$} & $\begin{array}{l}\text { Assuming } \\
\text { that the } \\
\text { variance } \\
\text { is equal. }\end{array}$ & $\begin{array}{c}1.62 \\
2\end{array}$ & $\begin{array}{c}.20 \\
6\end{array}$ & $\begin{array}{c}-2.16 \\
0\end{array}$ & 96 & .033 & -2.535 & 1.173 & -4.864 & -.206 \\
\hline & $\begin{array}{l}\text { Assuming } \\
\text { that the } \\
\text { variance } \\
\text { is not } \\
\text { equal. }\end{array}$ & & & $\begin{array}{c}-2.27 \\
9\end{array}$ & $\begin{array}{c}66.93 \\
9\end{array}$ & .026 & -2.535 & 1.112 & -4.755 & -.315 \\
\hline
\end{tabular}

Analyzing table 10 , it is known that the test result with memory as the goal is $\mathrm{P}=0.723>0.05$, no significant difference, and the test result with the comprehension and comprehensive use as the goal is $\mathrm{P}=0.033<0.05$, with significant difference. Therefore, compared with the traditional teaching mode, the flipped classroom teaching mode is more helpful for students to achieve the goal of understanding, comprehensive use and other high-level teaching objectives, and more importantly it has a significant role in promoting the development of students' cognitive ability.

\section{Conclusion}

In recent years, the reform of College English teaching has transited from the computer assisted instruction to autonomous learning combined with classroom teaching under the support of network platform. The application of flipped classroom teaching mode is a completely new exploration on College English classroom reconstruction. The application of the flipped classroom teaching mode in College English teaching, especially the elective course, is a bold attempt to integrate the educational technology with the College English curriculum. The practice of this study plays a valuable role in further promoting the application of the flipped classroom as a new teaching mode in College English elective course teaching. In the practice process of one semester, through the experimental study, 
action research and other research methods, we studied the application of flipped classroom teaching mode in College English teaching practice. The experimental results showed that in College English teaching, adopting flipped classroom teaching mode had a good effect in the overall turnover of the traditional teaching mode, and it effectively improved the enthusiasm of the students. Moreover, it stimulated students' desire for interaction and communication, and developed good communication habits and intercultural communication ability. At the same time, it had a significant role in promoting the development of students' cognitive ability.

\section{References}

[1] Yun Z. Study of flipped classroom model of college English class under the background of $\mathrm{Mu}[\mathrm{C}] / /$ International Conference on Social Science and Technology Education. 2015.

[2] Wang Y. Application on Flipped Classroom in College English Teaching[C]// International Conference on Social Science, Education and Humanities Research. 2016.

[3] Ogden L, Pyzdrowski L J, Shambaugh N. A Teaching Model for the College Algebra Flipped Classroom[J]. Promoting Active Learning Through the Flipped Classroom Model, 2014.

[4] Arai N, Akimoto T, Yamamoto E, et al. Poisson property of the occurrence of flip-flops in a model membrane.[J]. Journal of Chemical Physics, 2014, 140(6):064901.

[5] Kysh L. A Flip or a Flop?: Flipped PubMed Instruction for Health Sciences Students[C]// =medical Library Association Meeting. 2015. 